\title{
Processing of spent nickel catalyst for fat recovery
}

\author{
By Mohammad Ibrahim Nasir \\ Research Department, Jahan Vegetable Oil Co., \\ 16 Daman Afshar St., Wali - Assr Ave, Above Wanak Sq., Tehran - 19697, Iran \\ Fax : +9821 8885355
}

\section{RESUMEN}

\section{Procesado de catalizador agotado de níquel para la recuperación de su grasa.}

El catalizador agotado de níquel (SNC) tiene el potencial de dañar la calidad del medio ambiente de diversas formas. El depósito de SNC tendrá un efecto de polución. La recuperación óptima de la grasa a partir del SCN, podría conservar el medio ambiente y reducir la pérdida de aceite. El hexano ha sido el disolvente elegido para la extracción del aceite. También se han evaluado disolventes alternativos que son considerados seguros. Se han examinado hexano, isopropanol, etanol y heptano usando extracción con soxhlet. Mientras que el hexano fue el mas eficaz en la recuperación del aceite, el isopropanol demostró ser muy bueno para aclarar la separación del aceite a partir de la materia residual y también proporcionó una alta recuperación del disolvente en comparación con los otros disolventes. La extracción con isopropanol en frío proporcionó la separación de la miscela en dos fases: la mas baja rica en aceite y la mas alta rica en disolvente. Se ahorró mucha energía de vaporización durante la destilación. Se probó un proceso de extracción acuosa asistido con un solvente inmiscible, así un solvente como el hexano se añadió al SNC y posteriormente se le añadió agua con agitación continua. La mezcla se agitó durante 30 minutos, previo a la centrifugación. El proceso acuoso extrajo menos cantidad de aceite comparado con la extracción con disolvente.

PALABRAS-CLAVE: Catalizador agotado de níquel - Extracción con disolvente - Grasa - Isopropanol.

\section{SUMMARY}

\section{Processing of spent nickel catalyst for fat recovery.}

Spent nickel catalyst (SNC) have the potential of insulting the quality of the environment in a number of ways. The disposal of SNC will have a pollution effect. Optimum recovery of fat from SNC, could save the environment and reduce the oil loss. Hexane has been the solvent of choice for oil extraction. Alternative solvents that are considered safer have been evaluated. Hexane, isopropanol, ethanol, and heptane were examined using soxhlet extraction. While hexane was more efficient in oil recovery from SNC, isopropanol proved to be very good, to clarifying separation of oil from waste material and also provide high solvent recovery compared to other solvents. Isopropanol extraction with chill provided separation of miscella into two phases: lower oil-rich and an upper solvent - rich. It saved much energy of vaporization for distilling. An aqueous extraction process with immiscible solvent assisted was tested. Solvent like hexane added to SNC, and water added later with continuous stirring. The mixture was stirred for about 30 minutes, prior to centrifugation. Aqueous process extracted less amount of oil compared to solvent extraction.

KEY-WORDS: Fat - Isopropanol - Solvent extraction - Spent nickel catalyst.

\section{INTRODUCTION}

In edible oil industry, nickel catalyst is used for hydrogenation of liquid oil to modify their physicochemical properties into semisolid plastic fats. The nickel catalyst is deactivated in due course of time and become a waste material (Hastert, 1989; Massoumi and Kajbaf, 1979; Shukla et al., 1988). It should be deposited in disposal site strictly controlled so that groundwater, air and land adequately are protected and are not exposed to harmful amount of toxics. To prevent the contamination of groundwater, and other pollution activity, a landfill must extremely reliable protection. So, it looks that the disposal of SNC will be expensive. (Hastert, 1989; Mc Dermont, 1979).

The SNC contain about $40-50 \%$ of fat which is a valuable amount to recover for reuse as edible or for soap if it is not of good quality. In addition to $9-12 \%$ of nickel as well as filter aid which can be recovered and reuse in fat industry (Massoumi and Kajbaf, 1979; Rai et al., 1989). In this instance environment pollution caused by fat processing waste could be reduced by appropriate recovery of these waste material (Hastert, 1989; Liadakis et al., 1995). The impact of used catalyst treatment on environmental conservation was review by Hongo (Hongo, 1993).

In oil extraction, hexane is the solvent used more extensively. Since $\mathrm{n}$-hexane is considered hazardous air pollution, interest in alternatives substitute to hexane have been stimulated. Isopropanol, ethanol, heptane in addition to hexane have been tested in oil extraction from SNC in this research work.

Extraction of oil from oilseed flour, which is close to characteristics to SNC, have been done with aqueous - enzymatic process during the last three decades (Yoon et al, 1991). But no attempt has take place to extract oil from SNC by aqueous process.

The proposition of this investigation is to determine the feasibility of recovering fat and oil by aqueous process as well as by solvent extraction from SNC. In addition, to find a better alternative substitute to hexane, a solvent considered safer than hexane, in the extraction of oil from SNC. One of the objects of this study is to optimize the recovery of solvent through testing isopropanol extraction with 
chill separation of miscella to save the energy of vaporization for distilling.

\section{EXPERIMENTAL}

\subsection{Material}

Samples of SNC were obtained from Jahan Vegetable Oil Co. plant in Karaj, Iran. The samples were removed warm directly after filtration and sealed into airtight containers and were stored after one hour at $-20^{\circ} \mathrm{C}$ until extraction. All chemicals and solvents used were of analytical grade or above of E-Merck (Germany) or Fluka (Switzerland).

\subsection{Procedures and apparatus}

The extraction of fats from SNC was done by a soxhlet extractor of $25 \mathrm{~g}$ for different periods (2-8 $\mathrm{h}$ ) with hexane and isopropanol as solvent. The solvent to SNC ratio in the extractor was 10:1 and 12:1 (W/V) with hexane and 12:1 with isopropanol and other solvents. Ethanol and heptane were examined for 4-hrs period only. The temperatures in the extractor were around $65^{\circ} \mathrm{C}$ for hexane, $78^{\circ} \mathrm{C}$ for isopropanol and ethanol and $88^{\circ} \mathrm{C}$ for heptane. The miscella obtained was distilled off on a water bath and hence under reduced pressure for recovery of solvent (Raie et al., 1989) except heptane, was distilled without water bath. The oil solvent free was stored at $-20^{\circ} \mathrm{C}$ until use. For chill separation isopropanol miscella were chilled to about $5^{\circ} \mathrm{C}$ in refrigerator over night to separate into lower oil phase and upper isopropanol phase by gravity. The lower phase was removed by decanting.

The aqueous extraction was done with $10 \mathrm{~g}$ of SNC with 10 and $15 \mathrm{~mL}$ of hexane as assisted solvent and stirred at about $40^{\circ} \mathrm{C}$ on heater - stirrer (IKAMAG, Jance and Kanakel, Germany) for 20 minutes and then $40 \mathrm{~mL}$ water was added with continuous stirring for other $30 \mathrm{~min}$. Hexane was distilled for recovery before the miscella centrifugation. The remain material was centrifuged with a laboratory centrifuge (Hermle ZK 380, Germany) with $9000 \mathrm{rpm}$ for $40 \mathrm{~min}$. at temperature of $38^{\circ} \mathrm{C}$, and miscella was separated into three layers of solids, water and oil. The top layer was pipette away for oil determination.

Recovery of nickel from SNC for estimation was done by digested the defated material $(10 \mathrm{~g})$ with $1: 5$ ratio (W/V) of $2 \mathrm{M}$ sulphuric acid for duration of two hrs at $95^{\circ} \mathrm{C}$. Then it was filtered. The filtrated was treated with nitric acid at $100^{\circ} \mathrm{C}$ for $90 \mathrm{~min}$. to convert iron from ferrous to ferric form. The solution then neutralized with $2 \mathrm{~N}$ sodium hydroxide to $\mathrm{pH} 6$ to precipitate the ferric hydroxide, which was removed by filtration. The filtrate was analyzed for its nickel content.

\subsection{Analysis}

The free fatty acid (FFA) content in the oil and iodine values was determined according to the AOCS procedures. (Metcalfe, 1979). The spent catalyst was analyzed for its moisture content by weight loss from $10 \mathrm{~g}$ sample dried at $100 \pm 2^{\circ} \mathrm{C}$ for two hrs (2). The fat content was determined by gravimetric method. Nickel content was determined gravimetrically using dimethylglyoxime and volumetrically with EDTA (Nasir et al, 1993; Vogel, 1978). Iron was determined gravimetrically by weighting the dry ferric hydroxide and volumetrically with EDTA (Nasir and Mohan, 1992; Vogel, 1978). Melting points were determined using the capillary tube method (AOAC, 1990). Fatty acid composition of the fat was determined by transesterification with sodium methoxid and analysis of the methyl esters by gas chromatography using a Varian Star $3400 \mathrm{CX}$ GC equipped with flame ionization detector and $2 \mathrm{~m}$ column packed with $20 \%$ DEGS on $80-100$ mesh chromosorb W support at column temperature of $180^{\circ} \mathrm{C}$ and injection port and FID temperature at $210^{\circ} \mathrm{C}$. Nitrogen was used as carrier gas. The composition of each peak was identified with those of standards run on the same column under similar conditions.

\section{RESULTS AND DISCUSSION}

Utilization of SNC was mainly to recover nickel (Massoumi and Kajbaf, 1979; Shukla et al., 1988; Applewhite, 1980) and very scanty work have done to recover fat (Raie et al., 1989).

The fat from SNC was extracted with soxhlet using hexane, isopropanol, ethanol and heptane as solvent. The composition of the SNC extracted with hexane is presented in Table I. The appreciable proposition of $2.3 \%$ iron impurity in the SNC most probably due to the use of mild steel hydrogenation vessel. The nickel content of $9.9 \%$ is less than half of the parent catalyst, which was $23 \%$. The relatively high values of standard deviation of oil perhaps are as results of changing the amounts of fresh catalyst used for hydrogenation in some batch of the process to speed up the hydrogenation. Other cause could be the tendency of solvent to channel and fine particles to pack (Nieh and Snyder, 1991) as such the solvent will not be able to penetrate to all SNC parts and that may make a difference in oil extracted by solvent (Dahlen and Lindh, 1983).

It has been noticed that if the fresh SNC is processed a white fat is recovered otherwise light yellow colour fat is obtained due to oxidation. While in the first case the quality of fat is such that it can be utilized for edible purposes, where as coloured fat can be used for the soap production.

The characteristics of oil extracted from SNC are shown in Table II. The low iodine value (50) 
Table I

Composition of spent nickel catalyst $^{\text {a }}$

\begin{tabular}{lc}
\hline \multicolumn{1}{c}{ Constituent } & content $(\%)^{\mathrm{b}}$ \\
\hline Moisture & $1.7 \pm 0.1$ \\
Iron & $2.3 \pm 0.2$ \\
Nickel & $10.0 \pm 2.0$ \\
Inert material & $43.0 \pm 2.0$ \\
Fat & $44.0 \pm 4.0$ \\
\hline
\end{tabular}

a Fat extracted with hexane for a period of 4 hrs using soxhlet extractor. b Average of six determination from 3 samples, and standard deviation.

Table II

Characteristics of fat extracted within two days of obtaining with hexane from spent catalyst ${ }^{a}$

\begin{tabular}{lc}
\hline \multicolumn{1}{c}{ Item } & Value \\
\hline Free fatty acid & 0.10 \\
lodine value & 50 \\
Melting point & $51^{\circ} \mathrm{C}$ \\
\hline
\end{tabular}

a Average of three determinations.

compared to that the fat produced by catalyst hydrogenation (75-80), perhaps due to the accumulation of more hydrogenated fat on the catalyst. It seem that the low temperature $\left(-20^{\circ} \mathrm{C}\right)$ and airtight container did not stop the oxidation of the fat, may be due to high amount of heavy metal (iron) in the fat. Table III shows the effect of time on FFA of the fat.

For optimum recovery of fat from spent catalyst, experiment was performed with varying the amount of solvents used as well as extraction time.

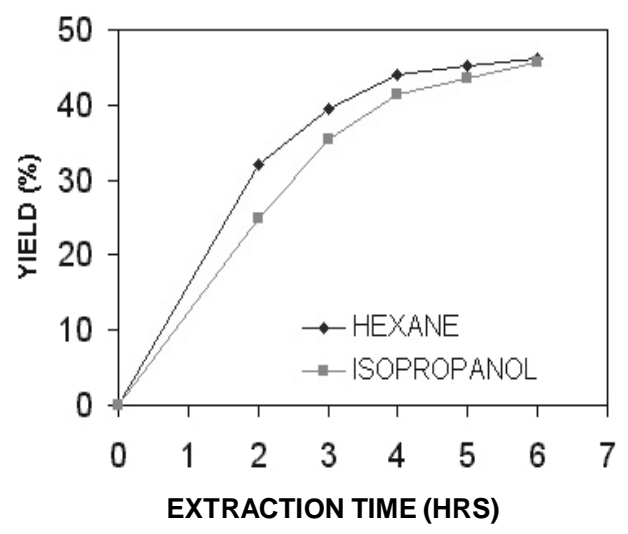

Figure 1

Fat recovery (yield \%) from $25 \mathrm{~g}$ of SNC with $300 \mathrm{~mL}$ hexane or isopropanol as a function of the extraction time*.

* Each value is average of at least 9 determinations of 3 samples.
Table III

The effect of time on the acidity of spent nickel catalyst fat $^{\text {a }}$

\begin{tabular}{rrr}
\hline No. & time & FFA \\
\hline 1 & 2 days & 0.10 \\
2 & 3 days & 0.18 \\
3 & 5 days & 0.28 \\
4 & 12 days & 0.40 \\
5 & 60 days & 0.60 \\
\hline
\end{tabular}

a Average of three determinations.

Increasing the amount of solvent (hexane) from 250 $\mathrm{mL}$ to $300 \mathrm{~mL}$ for $25 \mathrm{~g}$ of SNC resulted in increases the amount of oil extracted from $40.1 \%$ to $44.0 \%$. It seems that the ratio of $12: 1(\mathrm{~V} / \mathrm{W})$ of solvent to waste materials is the optimum ratio, as further increase did not significantly increase the amount of extracted oil. There is also increase in solvent loss with the increasing of solvent ratio. That may be due to increase in vapour pressure of the solvent.

Figure 1 show that there is steady increase of fat yield with the increasing extraction times. The amount of fat extracted by hexane with different periods, more than that extracted by isopropanol. Isopropanol extracted more slowly the fat than hexane (Lusas et al., 1997). Hexane is more efficient solvent for dissolving fat and it time interval for flashing the oil is $10 \mathrm{~min}$. while it is $14 \mathrm{~min}$ for isopropanol. For hexane, there is rapid increase in fat yield in the beginning of 4-hrs extraction time, while there is small increase in fat yield continuously in case of isopropanol. The recovery of hexane after extraction and distillation was $88.5 \%$ and $85 \%$ for 2 and $6 \mathrm{hrs}$ extraction times, respectively. For isopropanol it is $94.5 \%$ and $94 \%$ for 2 and $6 \mathrm{hrs}$ extraction times, respectively.

The difference in the heat of vaporization (cal / g) which is 80 for hexane and 206 for isopropanol (Baker and Sullivan, 1983). This required greater energy for isopropanol recovery through distillation. Another point in comparison of hexane with isopropanol is the filterability. A clear separation of the oil from nickel catalyst was achieved when isopropanol used, while hexane did not provide that clear separation. This is in agreement with what Hennion reported (Hennion, 1985). In addition isopropanol is safer (Baker and Sullivan, 1983; Horn et al., 1994). In chill separation at about $5^{\circ} \mathrm{C}$, the lower phase was removed by decanting contain $86.20 \%$ fat, while the solvent phase contain about $2.0 \%$ oil. Commercially the process can be hastened with heat exchanger and centrifuges with less time and less energy than that used in vaporization (Lusas et al., 1997). 
Table IV

Fatty acid composition (\%) of the oil before and after hydrogenation *

\begin{tabular}{llrrr}
\hline Fatty acid & $\begin{array}{c}\text { Before } \\
\text { hydrogenation } \\
\text { (IV=130) }\end{array}$ & $\begin{array}{c}\text { Hydrogenated } \\
\text { (IV=76) }\end{array}$ & $\begin{array}{c}\text { Recovered }^{b} \\
\text { (IV=50) }\end{array}$ \\
\hline Palmitc & C & 11.2 & 11.2 & 11.2 \\
16:0 & & 4.0 & 9.1 & 35.0 \\
Stearic & $\mathrm{C}$ & 22.8 & 64.8 & 49.4 \\
18:0 & & 55.4 & 12.7 & 3.4 \\
Oleic & $\mathrm{C}$ & 5.2 & 1.2 & \\
18:1 & & & & \\
Linoleic & & & & \\
C18:2 & & & & \\
Linolenic & $\mathrm{C}$ & & & \\
18:3 & & & & \\
\hline
\end{tabular}

a Data from the supplier of blend soybean, cotton seed, and sunflo-

Ethanol is less efficient than isopropanol in oil dissolution, but it has better filterability than that of hexane. Ethanol yields less oil than what isopropanol yield in the same conditions ( $300 \mathrm{~mL}: 25 \mathrm{~g}$, for $4 \mathrm{hrs}$ ). Heptane is as good as ethanol but with poor filterability and required more energy than other solvents tested here.

Fatty acid composition of the oil before and after hydrogenation is shown in Table IV. It contains 3.4\% of polyunsaturated fatty acid, which is the main target of fat oxidation. There are $46.2 \%$ of saturated fatty acids and $52.8 \%$ of unsaturated which can be fitted for soap preparation if these can not be used for edible purposes.

Aqueous extraction of oil is an alternative procedure in oil extraction as it is the safest and it is not hazardous. The use of water alone did not give any result, in spite off strong mechanical agitation. It is due to strong clench of oil to the catalyst material. Hexane is used as immiscible assisted solvent with a ratio of $1: 1(\mathrm{w} / \mathrm{v})$ of catalyst to solvent but it gives poor results. There is about $22 \%$ oil yield which is nearly half that of solvent extraction, with little fine particles from defated catalyst material float on the oil top layer which did not settle easily by gravity in the solid bottom layer and centrifuge (having fixed angle rotor) used in this study could not separate the fine particles from miscella (oil) effectively .

Increasing the solvent ratio to $1: 1.5(\mathrm{~W} / \mathrm{V})$, it did not increase the yield significantly. Hexane recovery in the aqueous process is about $90 \%$.

These are few points of comparison between aqueous and solvent process. The solvent extraction is more efficient in oil extraction than aqueous extraction. The aqueous process is highly dependent on centrifuge which necessitate high maintenance and energy consumption, while in solvent extraction it is not required.

\section{CONCLUSION}

Environmental pollution caused by fat processing wastes could be reduced by appropriate recovery of edible and nonedible materials. Fat recovery from SNC with isopropanol as solvent serves this proposes. Isopropanol is safer and less toxic compared with hexane and it has high ratio of recovery as well as a very good filterability. Chill separation will save much energy used in heat of vaporization.

Recovered fat can be utilized for edible or soap proposes. Recovery of fat will increase the nickel content in the defated material and that will increase its marketplace values for the reclaimed processing market (Hastert, 1989). Aqueous extraction is a less efficient technique for fat recovery from SNC.

Since complete defated materials of SNC is very fine powder which is difficult to handle and toxic (NDI, 1994) , it is advisable to recover about 98-99\% of fat from SNC, so that it can be handled easy.

\section{ACKNOWLEDGEMENT}

The author thanks Dr. M.J. Rasaee of Tarbiat Moddares University, Tehran for the assistance during the research work.

\section{REFERENCES}

AOAC. Official Methods of Analysis (1990) Method 920-157, 15 th ed.pp.954, AOAC Washington.

Applewhite, T.H. (1980) Fat and Fatty Oils in KIRK-OTHMER Encyclopedia of Chemical Technology, Vol.9, P 795-831, Mark, H.F, Overger, C.G., Seaburg, G.T (Ed.), John Wiley \& Sons., New York.

Baker, E.C. and Sullivan, D.A. (1983). Development of a pilot-plant process for the extraction of soy flakes with aqueous isopropyl alcohol. J. Am. Oil Chem. Soc. 60, 1271-1276.

Dahlen, J.A.H. and Lindh, L.A. (1983). Mass balance of hexane losses in an extraction plant. J. Am. Oil Chem. Soc. 60, 2009-2011.

Hastert, R.C. (1989). Disposition of spent nickel catalyst. J. Am. Oil Chem. Soc. 66, 174-176.

Hennion, F.J. (1985). The reclamation of spent hydrogenation catalyst. In. Proc. World Conf. Emerging Technol. Fats Oils Industry (Baldwin, A. R. Ed.) P. 172-183, AOCS, Champaign.

Hongo, K. (1993). Contribution of catalyst regeneration business to environmental conservation, Shokubai, 35, 245-249. In Chem. Bast. 116: 187713, 1993.

Horn, R.J., Kak, M.S, Abraham, G. and Wan, P.J. (1994). Ethanol extraction of oil, gossypol and aflatoxin from cottonseed. J. Am. Oil Chem. Soc. 71, 417-421.

Liadakis, G.N., Tzia, C., Oreopuplou, V. and Thompoulus, C.D. (1995). Protein insulation tomato seed meat, extraction optimization. J. Food Sci. 60, 477-482.

Lusas, E.W., Watkins, L. R., Koseoglu, S. S., Rhee, K. C., Hernandez, E., Riaz, M. N. \& Johnson, W.H. (1997) Final report: IPA as an extraction solvent. INFORM, 8, 290-306. 
Massoumi, A. and Kajbaf, M. A. (1979). Regeneration of used nickel catalyst. J. Am. Oil Chem. Soc. 56, 565-568.

McDermont, G.N. (1979). Pollution control in the fatty acid industry. J. Am. Oil Chem. Soc. 56, 789 A - 792 A.

Metcalfe, L.D. (1979). Traditional analytical chemistry of fatty acid and their derivation. J. Am. Oil Chem. Soc. 56, 786A- 789 A.

Nasir, M.I. and Mahan, A. (1992). Anion exchange selectivity's of $\mathrm{Zn}$ (II), Cd (II), $\mathrm{Hg}$ (II) and $\mathrm{Ba}$ (II) in $\mathrm{KI}$ solutions. Indian J. Chem. 31A, 285-287.

Nasir, M.I., Mahan, A., Rahman, N. and Khan, M.A. (1993). Sorption studies on some metal ions on a cation exchange resin in ammonium sulphamate medium. Chem. Anal. (Warsaw), 38, 169-174.

Nickel Development Institute (1994) Safe use of nickel in the work places, NDI, Toronto, p. 20-29.
Nieh, C.D. and Snyder, H.E. (1991). Solvent extraction of oil from soybean flour - pilot plane and two solvent extraction. J. Am. Oil Chem. Soc. 68, $250-253$.

Raie, M.Y., Ahmad, M. Ashraf, M. and Salma. (1989). The utilization of spent nickel catalyst. Pak.. J. Sci. Ind. Res. 32, 829-833.

Shukla, A., Maheshwari, P.N. and Vasishtha,. A. K. (1988). Reclamation of nickel from spent nickel catalyst. J.Am. Oil Chem. Soc. 65, 1816-823.

Vogel, A.I. (1978). Textbook of Quantitative Inorganic Analysis, 4 th Ed. ELBS / Longmont, London.

Yoon, S.H., Kim, I.H. and Kwon, T.W. (1991). Effect of enzyme treatment ultrasonification on extraction yield of lipid and protein from soybean by aqueous process. Korean. J. Food Sci. Technol. 23, 673-676. 